\title{
Morphological and molecular characterization of Setaria equina in donkeys
}

\author{
Mona Mohammed I. Abdel Rahman(D)
}

\begin{abstract}
Background: Adult worms of Setaria equina mainly found in the peritoneal cavity of equine. They were nonpathogenic but might induce varied degrees of peritonitis and might migrate to the eye, brain, lung, and scrotum causing lacrimation, blindness, paraplegia, locomotor, and neurological disturbances. Identification by light microscopy is insufficient to differentiate Setaria species, and so scanning electron microscopy (SEM) is required to observe their ultrastructures. The study was performed on 80 donkeys from May 2018 to January 2019 for the detection of microfilaria in blood and the adult worms in the peritoneal cavity. The blood samples were either stained with Giemsa stain or examined by modified Knott's technique for the detection of microfilariae. Adult worms were morphologically characterized based on light microscope and scanning electron microscopy (SEM). PCR was performed targeting the $12 \mathrm{~S}$ rRNA gene followed by sequencing and phylogenetic analysis.

Results: The current study recorded $21.6 \%$ and $16.2 \%$ prevalence rates for adult worms and microfilariae, respectively. By using SEM, this study was able to clarify the detailed structure of amphids, predeirids, vulva, arrangement, and number of male caudal papillae. PCR amplified products for $12 S$ rRNA gene (408 bp) for adult worm and microfilaria. Sequence and phylogenetic analysis revealed that S. equina isolated in the current study from donkeys in Egypt (accession no., MH345965) shared 100\% identity with isolates from horse and man in Italy and Iran, respectively and clustered in the same clade with S. digitata, S. tundra and S. labiatopapillosa.

Conclusions: Identification with light microscopy lacked the ability to characterize different Setaria species, and so using scanning electron microscopy is considered a good choice to distinguish the ultrastructures. In addition, performing the phylogenetic analysis was necessary to detect relationships between different filarial worms, which could not detect by the morphological characterization of adult worms.
\end{abstract}

Keywords: Equine, Microfilaria, Setaria equina, 125 rRNA, Ultrastructure

\section{Background}

Setaria equina (S. equina) is a common vector borne pathogen of equines all over the world, especially in tropical zones. S. equina transmitted by Aedes aegypti and Culex pipens where L1 developed to L3 within 2 weeks in their thoracic muscles. Then, the equines acquired the infection during mosquito's blood meal and the life cycle completed within 8-10 months [1]. Also,

Correspondence: mona_111_para@yahoo.com; mm_ibrahim@zu.edu.eg Department of Parasitology, Faculty of Veterinary Medicine, Zagazig University, 1 Alzeraa Street, Zagazig City, Sharkia Province 44511, Egypt prenatal infection reported as a route of transmission for Setaria species $[2,3]$.

Adult worms mainly found in the peritoneal cavity of horse and donkey. The worms were nonpathogenic but might induce varied degrees of peritonitis and might migrate to the eye, brain, lung, and scrotum of equines causing lacrimation, blindness, paraplegia, locomotor, and neurological disturbances $[4,5]$. Not only S. equina induced such pathogenic effects but also other Setaria species infect cattle (S. digitata and S.cervi) could induce blindness and CNS damage in equine where [6] recorded

\section{Springer Open}

(๑) The Author(s). 2020 Open Access This article is licensed under a Creative Commons Attribution 4.0 International License, which permits use, sharing, adaptation, distribution and reproduction in any medium or format, as long as you give appropriate credit to the original author(s) and the source, provide a link to the Creative Commons licence, and indicate if changes were made. The images or other third party material in this article are included in the article's Creative Commons licence, unless indicated otherwise in a credit line to the material. If material is not included in the article's Creative Commons licence and your intended use is not permitted by statutory regulation or exceeds the permitted use, you will need to obtain permission directly from the copyright holder. To view a copy of this licence, visit http://creativecommons.org/licenses/by/4.0/. 
horse blindness with $S$. digitata in Korea. Also, Abu ElMagd and Ahmed, Marzok and Desouky [3, 7] reported the aberrant parasitism of adult worms in eye of donkey in Egypt. Also, Nabie et al. and Taylor et al. [8, 9] stated the zoonotic importance of S. equina in man.

Many species of Setaria were reported all over the world, but S.equina considered the most popular species recorded in donkeys. In Egypt, S.equina had been studied by many authors in different Governorates [3, 7, 10-13]. The highest rate was recorded in Benha Governorate [14].

The diagnosis of microfilariasis depending upon the noticed clinical symptoms or serological tests is inaccurate, lacking the specificity and consuming time. As it is known that the DNA is stable in the life cycle stages of the parasite. Therefore, the PCR technique was performed in the current study to diagnose microfilariasis using the extracted DNA from adult worms and microfilariae of S.equina. In Egypt, many previous studies had used the adult worms of S.equina in PCR, but this study is the first of its kind that used both of adult worms and their corresponding microfilariae in PCR. Also, the previous studies had been characterized S.equina in horses, but fewer studies were known about donkeys. So the present study aimed to assess the following points: (a) investigate the prevalence rate of S. equina in donkeys in Egypt, (b) diagnose the microfilariae early in blood samples of infected donkeys, (c) identify the morphological features of the genus Setaria under the light microscope, (d) characterize and differentiate the detailed ultrastructures of the species equina from others like digitata or marsalli by scanning electron microscopy, and (e) detect the phylogenetic relationship between $S$. equina and other members of Filarioidea depended upon $12 S$ rRNA gene.

\section{Methods}

\subsection{Animals}

A total of 80 donkeys (10-30 years old) were examined during the period from May 2018 to January 2019 in Giza zoo, Dokki, Egypt.

\subsection{Sample collection and processing \\ 2.2.1 Adult worms}

Adult worms were collected from peritoneal cavity of donkeys at the time of necropsy, washed with saline, cleared with lactophenol, and identified under light microscope according to [15-17]. For the SEM, the adult worms were fixed in $2.5 \%$ buffered gluteraldehyde ( $\mathrm{pH} 7.2)$ for $24 \mathrm{~h}$, dehydrated in graded ethanol, mounted over the stubs, coated with gold coat, and examined with Quanta FEG250 scanning electron microscope, operated at $20 \mathrm{KV}$ in $\mathrm{Na}-$ tional Research Center, Dokki, Egypt $[5,18]$.

\subsubsection{Blood samples}

Ethylene Diamine Tetraacetic acid (EDTA) mixed blood samples were collected, stained with Giemsa stain, or examined by modified Knott's technique for detection of microfilariae according to [19].

\subsection{DNA extraction and PCR amplification}

DNA was extracted from adult worms and blood samples using the QIAamp DNA Mini kit (Qiagen, Germany, $\mathrm{GmbH}$ ), and subjected to PCR targeting the $12 \mathrm{~S}$ ribosomal RNA gene. PCR reaction was carried out in a 0.2 tube containing $1.5 \mu \mathrm{l}$ Max PCR Master Mix (Takara, Japan), $0.25 \mu \mathrm{l}$ of each primer (Bio Basic Canada Inc.), $5 \mu \mathrm{l}$ of DNA template, and up to $25 \mu \mathrm{l}$ nuclease free water. The PCR cycling program and primers sequences are listed in Table 1 [20].

\subsection{Phylogenetic analysis}

PCR products were purified by QIA quick PCR purification kit (Qiagen, Valencia) and sequenced by Big dye Terminator V3.1 cycle sequencing kit (Perkin-Elmer). DNA sequences were obtained by Applied Biosystems 3130 genetic analyzer (HITACHI, Japan) and a BLAST ${ }^{\circ}$ analysis (Basic Local Alignment Search Tool). The sequence analysis was performed by the MegAlign module of Lasergene DNAStar [21] and the phylogenetic tree generated by using maximum likelihood, neighbor joining, and maximum parsimony in MEGA 6[22]. The $12 S$ $r R N A$ gene sequences generated in this study was deposited in the GenBank under accession no. MH345965.

\section{Results \\ 3.1 Morphological characterization \\ 3.1.1 By naked eye}

Adult worms inside the peritoneum of donkeys appeared milky white and thread like. Their measurements reached $45-70 \mathrm{~mm}(57 \pm 2)$ long $\times 0.4-0.6 \mathrm{~mm}(0.45 \pm$ $0.02)$ wide in males with coiled end and reached $60-160$ $\mathrm{mm}(110 \pm 5)$ long $\times 0.6-0.91 \mathrm{~mm}(0.60 \pm 0.04)$ wide in females with loose spiral end (Fig. 1a, b). The prevalence

Table 1 PCR cycling program and primers sequences

\begin{tabular}{|c|c|c|c|c|c|c|c|c|c|c|}
\hline \multirow[t]{2}{*}{ Primer } & \multirow[t]{2}{*}{ Sequence 5"-3" } & \multirow[t]{2}{*}{ Start } & \multirow[t]{2}{*}{ Stop } & \multirow{2}{*}{$\begin{array}{l}\text { Product } \\
\text { length }\end{array}$} & \multirow[t]{2}{*}{ 1st De. } & \multicolumn{3}{|l|}{ Amplification } & \multirow[t]{2}{*}{ F. Ex. } & \multirow[t]{2}{*}{ Reference } \\
\hline & & & & & & $2^{\text {nd }}$ De. & An. & Ex. & & \\
\hline \multirow{2}{*}{$\begin{array}{l}12 \mathrm{SF} \\
12 \mathrm{SR}\end{array}$} & 5'-GTT CCA GAA TAA TCG GCT A-3' & 7484 & 7502 & \multirow[t]{2}{*}{$408 \mathrm{bp}$} & \multirow[t]{2}{*}{$94^{\circ} \mathrm{C} 5 \min$} & $94^{\circ} \mathrm{C} 1 \mathrm{~min}$ & \multirow[t]{2}{*}{$50^{\circ} \mathrm{C} 1 \mathrm{~min}$} & \multirow[t]{2}{*}{$72^{\circ} \mathrm{C} 1 \mathrm{~min}$} & \multirow[t]{2}{*}{$72^{\circ} \mathrm{C} 10 \mathrm{~min}$} & \multirow[t]{2}{*}[20]{} \\
\hline & 5'-ATT GAC GGA TG(AG) ताT GTA CC-3 & 7994 & 7975 & & & 40 cycles & & & & \\
\hline
\end{tabular}




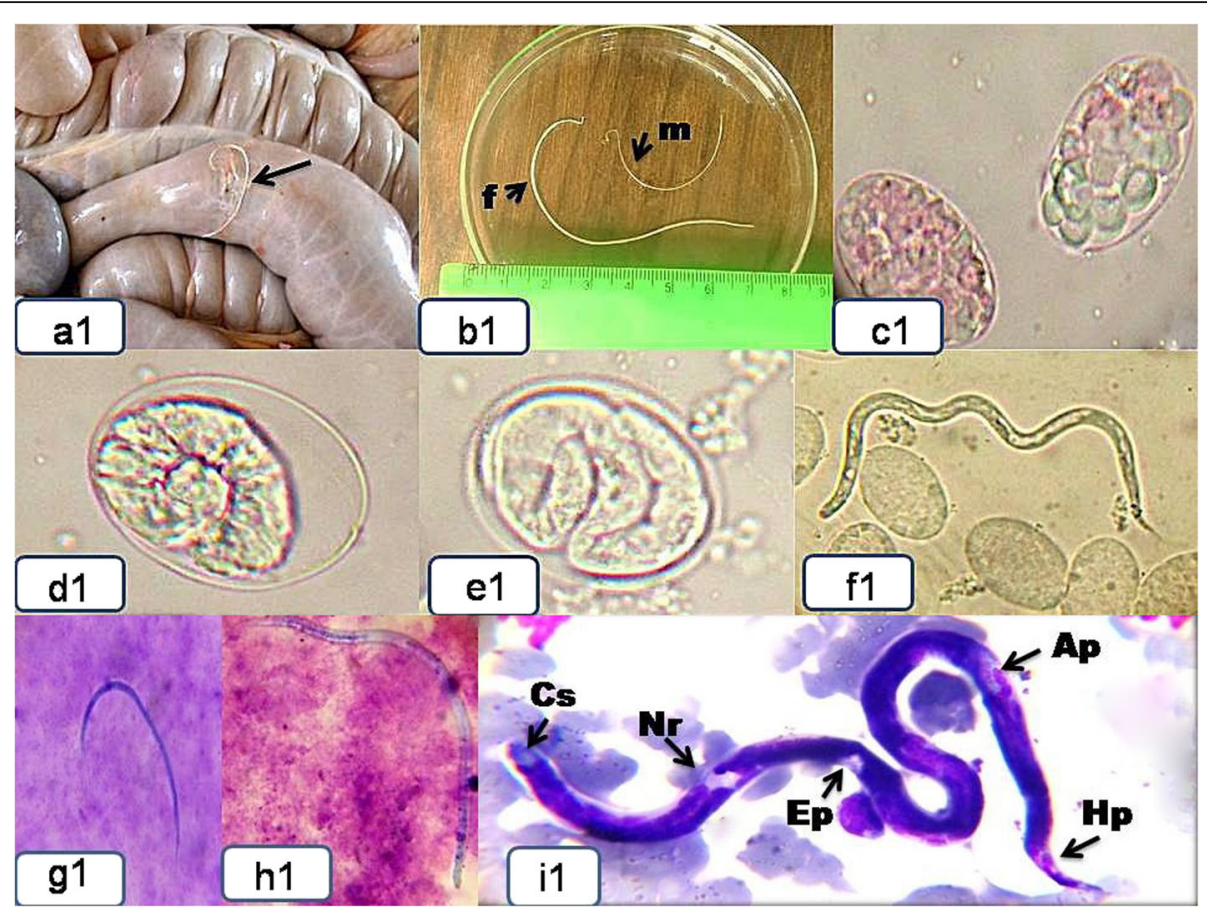

Fig. 1 Photos and microphotos of Setaria equina adult worm and its developmental stages. a1 Adult S. equina in peritoneum of donkey (arrow). b1 Male $(\mathrm{m})$ and female $(f)$ worms. c1 Embryonated egg ( $\times 100)$. d1 Egg with developing juvenile (J1) in coiled position ( $\times$ 100). e1 Egg contained fully extended $J 1(\times 100)$. f1 Free, full extended and sheathed $J 1(\times 100)$. g1, h1 Microfilaria in Knott's technique $(\times 100)$. i1 Giemsa stained microfilaria in blood film (Cs, cephalic space; $\mathrm{Nr}$, nerve ring; Ep, excretory pore; Ap, anal pore; Hp, hyaline process, $\times 400)$

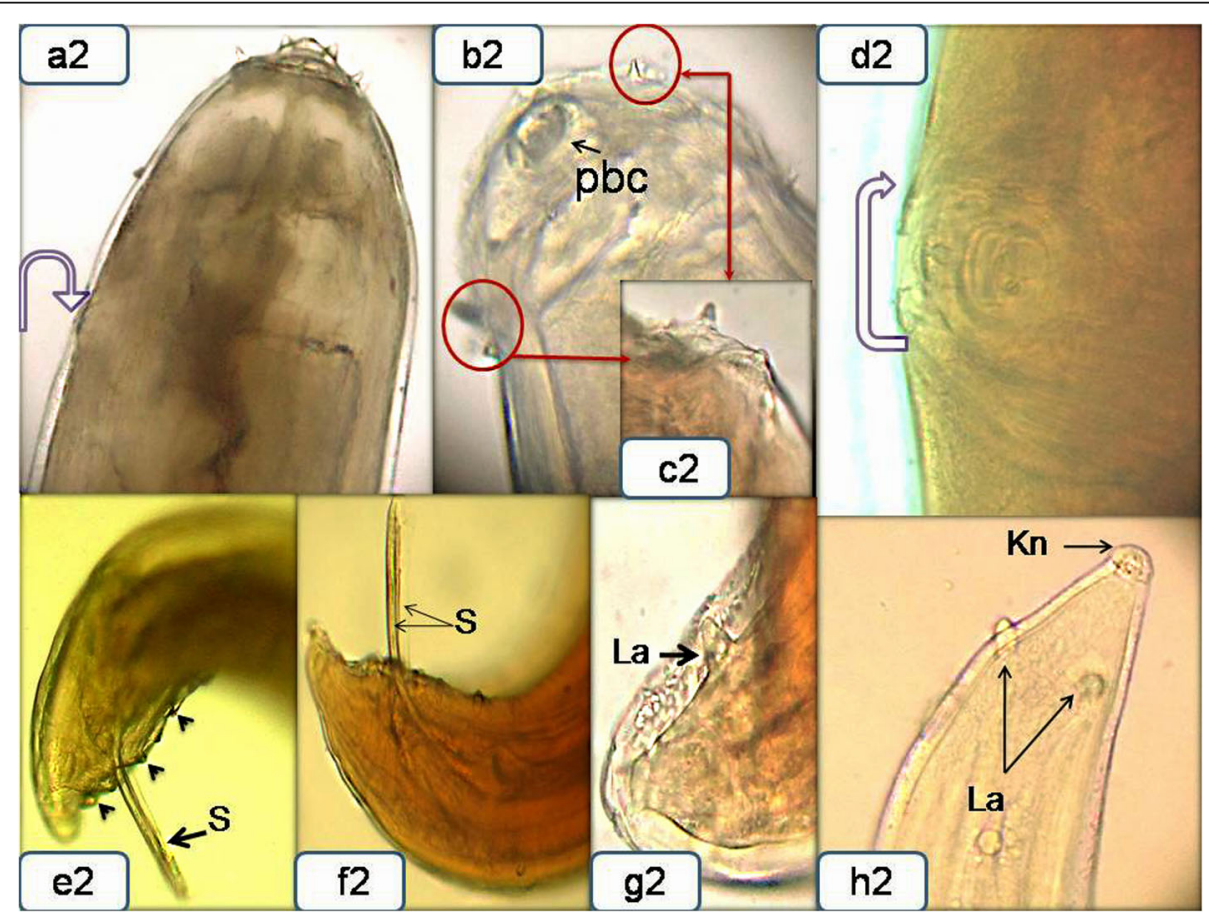

Fig. 2 Light microscopy of adult S. equina. a2 Anterior end of adult showing vulva (curved arrow) and mouth surrounded by labial and external labial papillae. b2 Anterior end of S. equina showing peribuccal crown (pbc) surrounded by external labial and cephalic papillae (red circles). $\mathbf{c 2}$ Higher magnification of external labial and cephalic papillae. d2 Vulva (curved arrow). e2, f2 Male caudal end carried spicules (S) and caudal papillae (arrow heads). $\mathbf{g} \mathbf{2}$ Lateral view of male tip tail carrying lateral appendage (La). h2 Female tail provided with pair of lateral appendages (La) and ended with smooth knob (Kn, Digital camera, $\times 100)$ 
rate of S. equina in the examined donkeys was $21.6 \%$ for adult worms in peritoneum.

\subsubsection{By light microscope}

The developmental stages of microfilaria from ovoidshaped eggs containing embryonic cells, developed or extended larvae (J1) to fully extended larvae were noticed under the light microscope (Fig. 1c-f). The sheathed microfilariae in blood samples reached 200$230 \mu \mathrm{m}$ long $\times 4.4-8.3 \mu \mathrm{m}$ wide and mainly detected at night and early morning. It appeared rounded anteriorly, tapered, and pointed posteriorly and filled with round nuclei. Also, the tip of the tail was characterized by a hyaline ovoid process. Giemsa stained microfilariae appeared brighter in cephalic space, excretory pore, nerve ring, and anal pore (Fig. 1g-i).

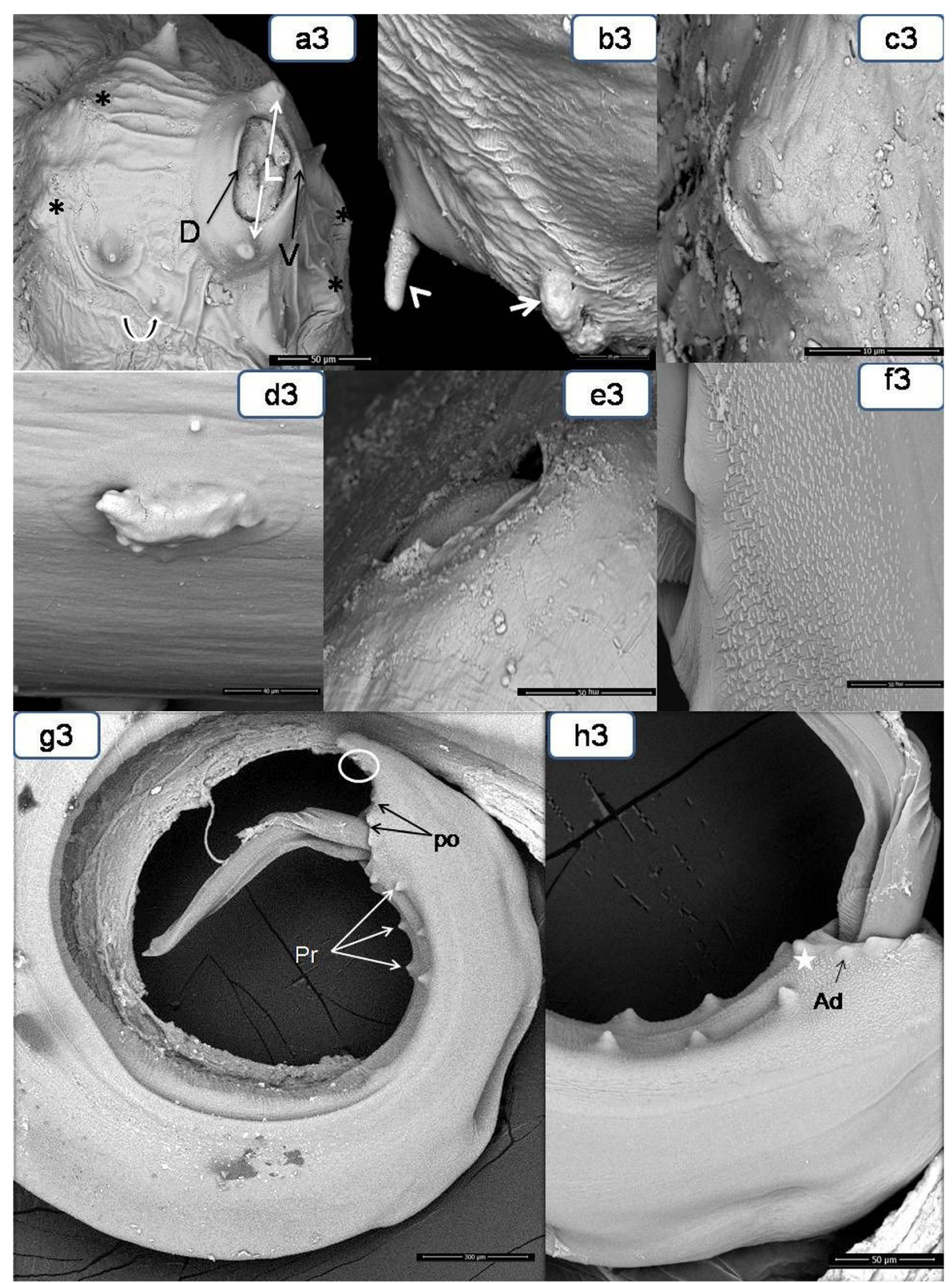

Fig. 3 Scanning electron micrograph of adult S. equina. a3 Oval oral opening was surrounded by dorsal (D) and ventral (V) lips, a pair of lateral labial papillae (L), two pairs of external labial papillae, two pairs of hilly elevated amphids (astriks), cephalic and smaller submedian papillae (curved arrow, $\times 1500$ ). b3 Higher magnification of cephalic (arrow) and external labial papillae (arrow head, $\times 6000$ ). c3 Higher magnification of amphid $(\times 12,000)$. d3 Predeirid $(\times 3000)$. e3 Vulva $(\times 6000)$. f3 Heavy tubercles in male caudal end $(\times 6000)$. g3, h3 Male caudal papillae arranged in three groups: 3 pairs precloacal (Pr), a pair of adcloacal (Ad), and 2 pairs postcloacal (Po) in addition to central papilla (star) and a pair of lateral appendages (white circle, $\times 400$ and $\times 1600$ ) 
Anterior end of adult worms characterized by oval oral opening which surrounded by peribuccal crown, a pair of labial papillae and two pairs of external labial papillae followed by cephalic papillae. The peribuccal crown consisted of dorsal and ventral lips in male and female adult worms (Fig. 2a, b, c). In females, the vulva located near the mouth $(0.5 \mathrm{~mm}$ distance, Fig. 2a, d). Male posterior end was coiled, carried ill-defined caudal papillae and a pair of unequal and dissimilar spicules (Fig. 2e, f). A pair of accessory lateral appendages located near the tip in both sexes (Fig. 2g, h). Female posterior was conical in shape with terminal, smooth knob (Fig. 2h). The prevalence rate of microfilariae in blood samples was $16.8 \%$.

\subsubsection{By scanning electron microscopy}

Scanning electron microscopy (SEM) showed that the peribuccal crown was followed by external labial papillae. Each papilla followed by cephalic (large, raised, and rounded) and smaller submedian papillae (Fig. 3a, b). Also, two pairs of hilly elevated amphids located at the lateral sides of peribuccal crown (Fig. 3c). The pre-deirid appeared in the form of cap-like with needle-like projection (Fig. 3d). Vulva presented at the anterior end and mainly covered by a flap (Fig. 3e). In males, the caudal papillae arranged in three groups: 3 pairs precloacal, a pair of adcloacal, and 2 pairs postcloacal in addition to central papilla and a pair of lateral appendages. The cuticle provided with minute heavy tubercles and fine longitudinal micro-striations (lugae/ventral bands) especially in male posterior end (Fig. 3f-h).

\subsection{Molecular and phylogenetic analysis}

PCR amplified the fragment of $12 \mathrm{~S}$ ribosomal RNA gene (408 bp) from both adult worms and microfilariae DNA (Fig. 4). The $12 S$ rRNA partial mitochondrial sequence for $S$. equina was sequenced and submitted in Genbank under the accession number MH345965. The Blast results for our sequence revealed $100 \%$ identical with $S$. equina (accession no., AJ544835 and KU291446) isolated from horse and man in Italy and Iran, respectively. The current phylogenetic tree based on $12 S$ rRNA gene sequences showed that $S$. equina shared the same clade with $S$. digitata, S. tundra, and $S$. labiatopapillosa, while Onchocercidae sp had a separate clade (Fig. 5). The used sample numbers and positive percentages are listed in Table 2.

\section{Discussion}

Filariosis is a major health problem in tropical countries. Filarial worms had significant morbidity resulted in reducing the working capacity of donkeys [18]. Setaria equina is one of filarial worms that infects donkeys and distributed all over the world. Adult worms had a little pathogenic effect in normal site (peritoneum) but they

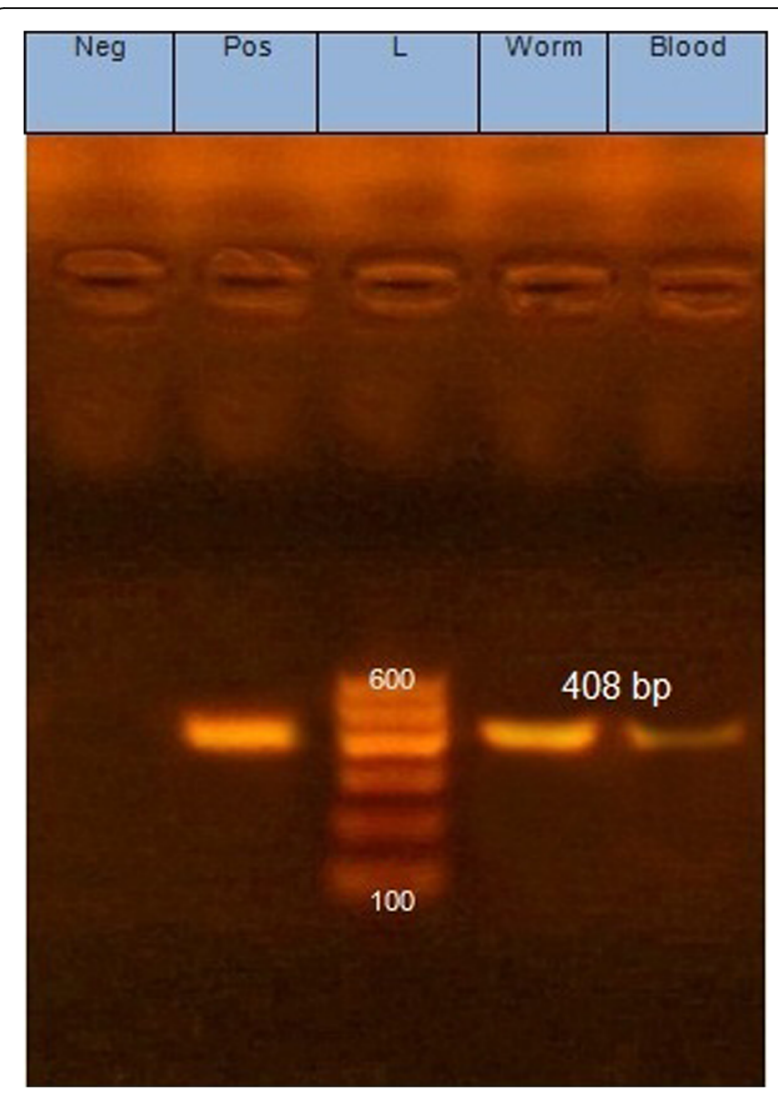

Fig. 4 Electrophoretic pattern of amplified PCR products for $S$. equina adult worm and microfilaria showing 408 bp in length. $L$, ladder; Pos, positive control; and Neg, negative control

may induce serious effects in aberrant sites like eyes and central nervous system.

The prevalence rate for S. equina adult worms was $21.6 \%$ in donkeys. Nearly similar rates were recorded in Assiut, Egypt [12, 23] 16\%. Lower rates were $11.9 \%$ in Iraq [24] and 12\% in Turkey [25]. Higher rates were recorded in Egypt to be $43.08 \%, 25 \%, 31.11 \%$, and $36.17 \%$ by $[14,26-28]$, respectively. This variance may be attributed to different seasons, temperatures, abundance of mosquito vectors, management, and animal factors (sex, age, and breed) [18, 29].

In spite of the inability of $[3,27]$ to detect microfilariae in the blood of infected donkeys, the current study recorded $16.8 \%$ prevalence rate for microfilariae. Also, Hadi and Atiyah [30] recorded 11.11\% infection rate in Baghdad, Iraq. Lower rates (4\%) were recorded in Assiut, Egypt, and in Turkey [25, 31]. This might be due to low parasitemia in the blood and nocturnal periodicity of microfilariae.

This study agreed with $[2,32]$ who recorded different developmental stages of eggs and larvae inside the uterus of Setaria species adult worms by light microscopy. Also, the studied morphological features of eggs, L1 and L3 were similar to those described by [18] in India. 


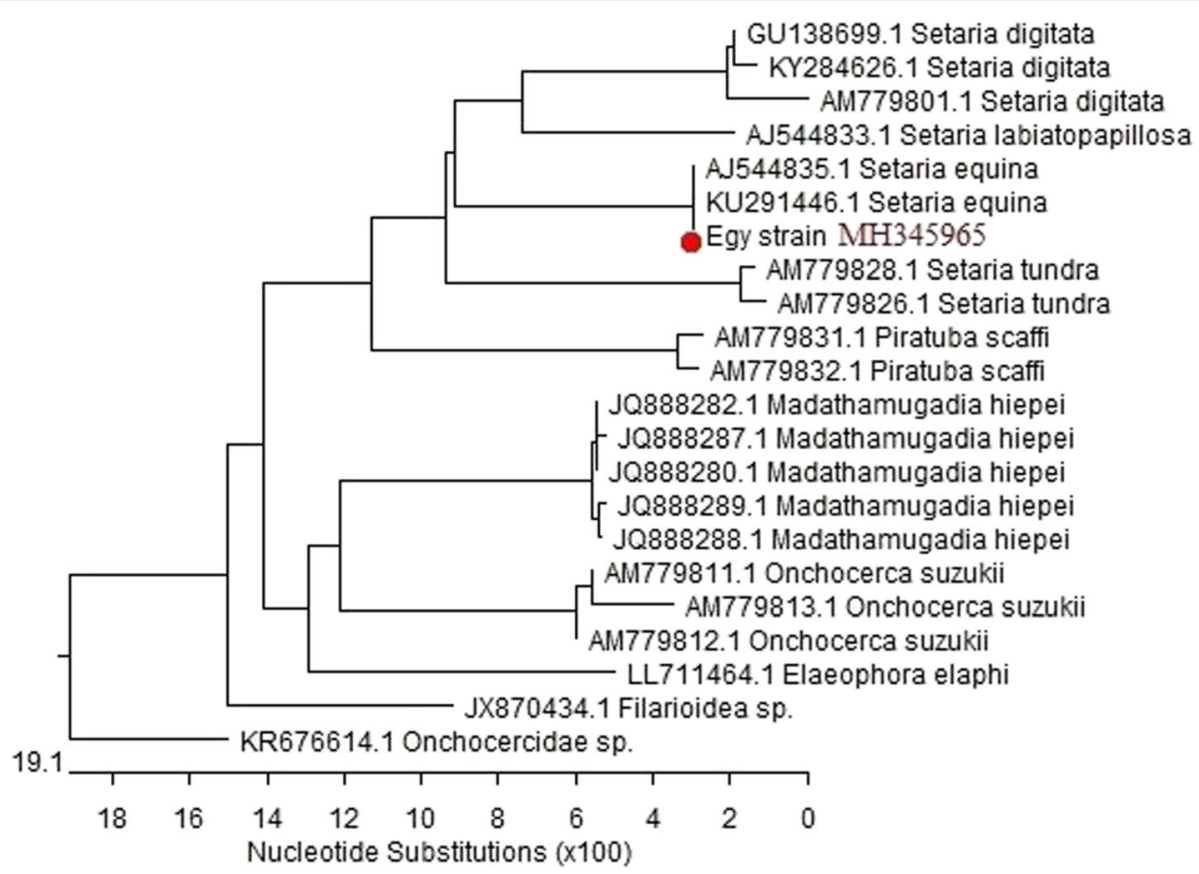

Fig. 5 Phylogenetic tree showing the genetic relationship between the $12 S \mathrm{rRNA}$ gene sequences of Setaria equina in this study (marked with red circle) and other sequences in the GenBank. The tree was generated maximum likelihood, neighbor joining and maximum parsimony in MEGA6 at 1000 bootstrap

The present study recorded the morphological characterization of S. equina in oral opening, papillae around the peribuccal crown, male and female caudal ends, amphids, deirids, ventral transverse bands, and the vulva ultrastrucures by usage of light and scanning electron microscopy. The obtained results for the morphological structures were similar to those described by [3, 11, 13, 25, 33].

Although [11] were unable to describe the arrangement of caudal papillae, the current study and [13] had a similar description of the number and arrangement of the caudal papillae in males. Otherwise, [33] found a pair of precloacal, a pair of postcloacal papillae, and an adcloacal papilla only to the right side in males of S. equina. Also, the location of amphids on both lateral sides was similar to [3, 11, 33], while [13] located them dorso-ventrally to the peribuccal crown. The caudal lateral appendages were clearly visible in both sexes by light and SEM examination in spite of $[13,33]$ who observed them more clearly in females than males by SEM and could not detect them by light microscopy. Presence of ventral bands and heavy tubercles in the posterior end of male was a characteristic for S. equina as stated by [13, 33], while Abd El-Wahab and Ashour [11] was unable to detect them.

In our study, PCR revealed that the length of PCR products was $408 \mathrm{bp}$. This result resembled to that obtained by $[8,20,34]$. Studying the phylogenetic relationships of Filarioidea is of great importance due to cross immune interactions between filarial worms where [35] stated the cross reactivity between $S$. equina and Wuchereria bancrofti in chronic infected patients. In this study, the obtained $12 S$ rRNA sequence for S. equina from donkey in Egypt (accession no., MH345965) and other (AJ544835) from horse in Italy recorded 100\% identity without any nucleotide substitution [8]. The current phylogenetic tree and $[10,20,34,36]$ showed that $S$. equina shared the same clade with $S$. labiatopapillosa, S. digitata, and S. tundra.

\section{Conclusion}

Identification with light microscopy lacked the ability to characterize different Setaria species, and so using scanning electron microscopy considered a good choice to distinguish the ultrastructures of amphids, deirids, and

Table 2 Samples numbers and positive percentages

\begin{tabular}{lllll}
\hline Examined no. & +ve no. & Infection (\%) & Collected adult worms no. & Samples no. subjected to PCR and sequences \\
\hline 80 & $27 \mathrm{w}$ & $21.6 \mathrm{~W}$ & $135(5$ worms/donkey) & all of +ve samples were used \\
& $20 \mathrm{~m}$ & $16.8 \mathrm{~m}$ & &
\end{tabular}

$m$ microfilariae, no. number, $+v e$ positive, $w$ adult worms 
papillae. In addition, it was necessary to perform the phylogenetic analysis and detect relationships between different filarial worms, which could not detect by the morphological characterization of adult worms. The obtained results in this study will be helpful to set programs for proper and an effective control strategy against filariasis specially $S$. equina in donkeys in Egypt. In addition, the early, sensitive, and specific diagnosis of S. equina microfilariae in blood samples by PCR will be crucial for rapid and effective treatments.

\section{Acknowledgements}

Not applicable

\section{Author's contributions}

Au designed the study, collected the samples, analyzed, interpreted the data, and prepared the manuscript. The author(s) read and approved the final manuscript.

\section{Funding}

Not applicable.

\section{Availability of data and materials}

Data sharing is not applicable to this article as no datasets were generated or analyzed during the current study.

\section{Ethics approval and consent to participate}

This study was approved ethically by ZU-IACUC Committee, Zagazig University, Egypt, with number ZU-IACUC/2/F/75/2018.

\section{Consent for publication}

Not applicable

\section{Competing interests}

No competing interests have been declared.

Received: 27 January 2020 Accepted: 13 March 2020

Published online: 01 June 2020

\section{References}

1. Perumal ANI, Gunawardene YINS, Dassanayake RS (2016) Setaria digitata in advancing our knowledge of human lymphatic filariasis. J Helminthol 90(02):129-138. https://doi.org/10.1017/s0022149x15000309

2. Kim NS, Kim HC, Sim C, Ji JR, Park BK (2010) Congenital infection with Setaria digitata and Setaria marshalli in the thoracic cavity of a Korean calf: a case report. Vet Med 55:275-280

3. Marzok MA, Desouky AR (2009) Ocular infection of donkeys (Equus asinus) with Setaria equina. Tropical Animal Health and Production 41(6):859-863. https://doi.org/10.1007/s11250-008-9263-x

4. Solusby EJL (1986) Helminths, arthropods and protozoa of domesticated animals. 7th ed. edn. Bailliere Tindall, London.

5. Rhee JK, Choi EY, Park BK, Jang BG (1994) Application of scanning electron microscopy in assessing the prevalence of some Setaria species in Korean cattle. Korean Journal of Parasitology 32(1):1-6

6. Shin J, Ahn KS, Suh GH, Kim HJ, Jeong HS, Kim BS, Choi E, Shin SS (2017) First blindness cases of horses infected with Setaria Digitata (Nematoda: Filarioidea) in the Republic of Korea. The Korean Journal of Parasitology 55(6):667-671. https://doi.org/10.3347/kjp.2017.55.6.667

7. Abu El-Magd A, Ahmed ZG (1994) The occurrence of Setaria equina in donkey's eyes and their treatment. Assiut Vet Med J 31:86-90

8. Nabie R, Spotin A, Rouhani S (2017) Subconjunctival setariasis due to Setaria equina infection; a case report and a literature review. Parasitology International 66(1):930-932. https://doi.org/10.1016/j.parint.2016.10.017

9. Taylor LH, Latham SM, Woolhouse MEJ (2001) Risk factors for human disease emergence. Philos Philosophical Transactions of the Royal Society London B 356:983-989. doi:doi.org/10.1098/rstb.2001.0888.
10. Abbas I, Al-Araby M, Al-Kappany Y (2016) Molecular characterization of Setaria equina infecting donkeys (Equus asinus) from Egypt. Res J Parasitol 11(3):73-78. https://doi.org/10.3923/jp.2016.73.78

11. Abd El-Wahab TM, Ashour AA (1999) Scanning electron microscopy of the two filariid nematodes Setaria equina and Onchocerca cervicalis from Kafr ElSheikh area, Egypt. Alexandria J Vet Sci 15(3):541-547

12. Mahmoud AE (1998) Laboratory diagnosis of filariasis in Assiut Governorate. M.V.Sc. thesis, Faculty of Medicine, Assiut University, Egypt.

13. Mahmoud AE (2006) A study of Setaria equina (Abildgaard, 1789) by light and scanning electron microscopy. EL-Minia Med Bullet 17(1):157-173

14. Ahmed NE, El-Akabawy LM, Ramadan MY, Radwan AMM (2011) Studies on helminth parasites in necropsied donkeys in Egypt. Benha Vet Med J 1:153-162

15. Anderson RC (1968) The comparative morphology of cephalic structures in the superfamily Filarioidea (Nematoda). Canadian Journal of Zoology 46: 181-199

16. Becklund WW, Walker ML (1969) Taxonomy, hosts, and geographic distribution of the Setaria (Nematoda: Filarioidea) in the United States and Canada. J Parasitol 55(2):359-368

17. Thwaite JW (2016) The genus Setaria. Annals Tropical Med Parasitol 21(4): 427-466. https://doi.org/10.1080/00034983.1927.11684550

18. Kumar LR (2013) Nucleic acid based diagnosis of concurrent incidence of bovine and caprine microfilariosis due to Setaria digitata. M.V.Sc. Thesis., Sri Venkateswara Veterinary University India.

19. Sloss MW, Kemp RL, Zajac AM (1994) Veterinary clinical parasitology . 6th edi. edn. Iowa State University Press, Ames. India

20. Casiraghi M, Bain O, Guerrero R, Martin C, Pocacqua V, Gardner SL, Francheschi A, Bandi C (2004) Mapping the presence of Wolbachia pipientis on the phylogeny of filarial nematodes: evidence for symbiont loss during evolution. Int J Parasitol 34(2):191-203. https://doi.org/10.1136/vr.161.24.814

21. Thompson JD, Higgins DG, Gibson TJ (1994) Clustal W: improving the sensitivity of progressive multiple sequence alignment through sequence weighting, position-specific gap penalties and weight matrix choice. Nucleic Acids Research 22(22):4673-4680

22. Tamura K, Stecher G, Peterson D, Filipski A, Kumar S (2013) Mega 6 : molecular evolutionary genetics analysis version 6.0. Molecular Biology and Evolution 30(12):2725-2729

23. Sakal AA, Hassan AA, Dyab AK, Mahmoud AE (2000) Parasitological studies on filariasis in Assiut Governorate. Assiut Med J 24(1):29-35

24. Al-Azawi KA, Fadhl RA, Fadhl RS (2012) Epidemiological study of Setaria equina infection in donkeys. Iraq Vet J 36(2):93-97

25. Oge S, Oge H, Yildirim A, Kircali F (2003) Setaria equina infection of Turkish equines: estimates of prevalence based on necropsy and the detection of microfilaraemia. Annals Tropical Med Parasitol 97(4):403-409. https://doi.org/ 10.1179/000349803235002434

26. Attia MM, Khalifa MM, Atwa MT (2018) The prevalence and intensity of external and internal parasites in working donkeys (Equus asinus) in Egypt. Veterinary World 11(9):1298-1306. https://doi.org/10.14202/vetworld.2018. 1298-1306

27. Radwan AM, Ahmed NE, Elakabawy LM, Ramadan MY, Elmadawy RS (2016) Prevalence and pathogenesis of some filarial nematodes infecting donkeys in Egypt. Veterinary World 9(15):888-892

28. Radwan AMM (1999) An investigation on parasitic infection in equines. M.V. Sc. Thesis, Faculty of Veterinary Medicine, Benha University.

29. Davoodi J (2015) Prevalence of setariosis in small and large ruminant in Miyaneh City, Northweast of Iran. GMP Rev 18(2):813-817

30. Hadi AM, Atiyah AH (2014) Isolation and identification of blood parasites from equine in Baghdad. Paper presented at the First scientific conference for medical and health, Baghdad, Iraq

31. Arafe MI (1998) Studies on ecto and endo parasites of equines in Assiut Governorate. Ph.D., Faculty of Veterinary Medicine, Assiut University.

32. Sahu BR, Mohanty MC, Sahoo PK, Satapathy AK, Ravindran B (2008) Protective immunity in human filariasis: a role for parasite-specific lgA responses. J Infectious Dis 198(3):434-443. https://doi.org/10.1086/589881

33. Shoho C, Uni S (1977) Scanning electron microscopy (SEM) of some Setaria Species (Filarioidea, Nematoda). Zeitschrift Fur Parasitenkunde 53:93-104

34. Yatawara L, Wickramasinghe S, Nagataki M, Rajapakse RP, Agatsuma T (2007) Molecular characterization and phylogenetic analysis of Setaria digitata of Sri Lanka based on CO1 and 12S rDNA genes. Veterinary Parasitology 148(2):161-165. https://doi.org/10.1016/j.vetpar.2007.06.005

35. Bahgat MM, Saad AH, El-Shahawi GA, Gad AM, Ramzy RM, Ruppel A, AbdelLatif M (2011) Cross-reaction of antigen preparations from adult and larval 
stages of the parasite Setaria equina with sera from infected humans with Wuchereria bancrofti. Eastern Mediterranean Health J 17(8):679-686

36. Alasaad S, Pascucci I, Jowers MJ, Soriguer RC, Zhu XQ, Rossi L (2012) Phylogenetic study of Setaria cervi based on mitochondrial cox 1 gene sequences. Parasitology Research 110(1):281-285. https://doi.org/10.1007/ s00436-011-2486-1

\section{Publisher's Note}

Springer Nature remains neutral with regard to jurisdictional claims in published maps and institutional affiliations.

Submit your manuscript to a SpringerOpen ${ }^{\circ}$ journal and benefit from:

- Convenient online submission

- Rigorous peer review

- Open access: articles freely available online

High visibility within the field

- Retaining the copyright to your article

Submit your next manuscript at $\boldsymbol{\nabla}$ springeropen.com 